\title{
T PLUTONISM IN JAPAN AND KOREA
}

by

Paul C. Batemar

Prior to the 1972 launching of IGCP's Circum-Pacific Plutonism Project, few of the project members even knew the names of their fellow workers elsewhere around the Pacific. The project has now held field excursions in all of the major landmasses bordering the Pacific, and an estimated 500 scientists have participated in its meetings or field trips. Project leader Paul Bateman summarizes some of the key geological observations made in Japan and in South Korea by participants in the recent highly successful 7 th meeting, which attracted some 100 geoscientists from ten Circum-Pacific countries.

\section{Introduction}

Assembling in Nagoya, Japan late in August of 1977, participants in the 7 th meeting of the IGCP Circum-Pacific Plutonism Project departed on a field trip that crossed the main structural belts of the inner zone of southwest Japan. It ended in Toyama, where a symposium on plutonism in relation to volcanism and metamorphism was held August 27-28 at Toyama University. We then moved on to Pusan, Korea to examine the geology across the structural belts of South Korea, arriving in Seoul on the 2nd of September. Three optional field trips followed - a one-day trip to the Precambrian terrain northeast of Seoul, a three-day trip to examine the Sangdong scheelite mine, and a three-day trip to the Yonwa base-metal mine.

Some eighty persons took part in the activities held in Japan; 34 continued on to Korea where they were joined by 14 Koreans who had not been in Japan. The countries

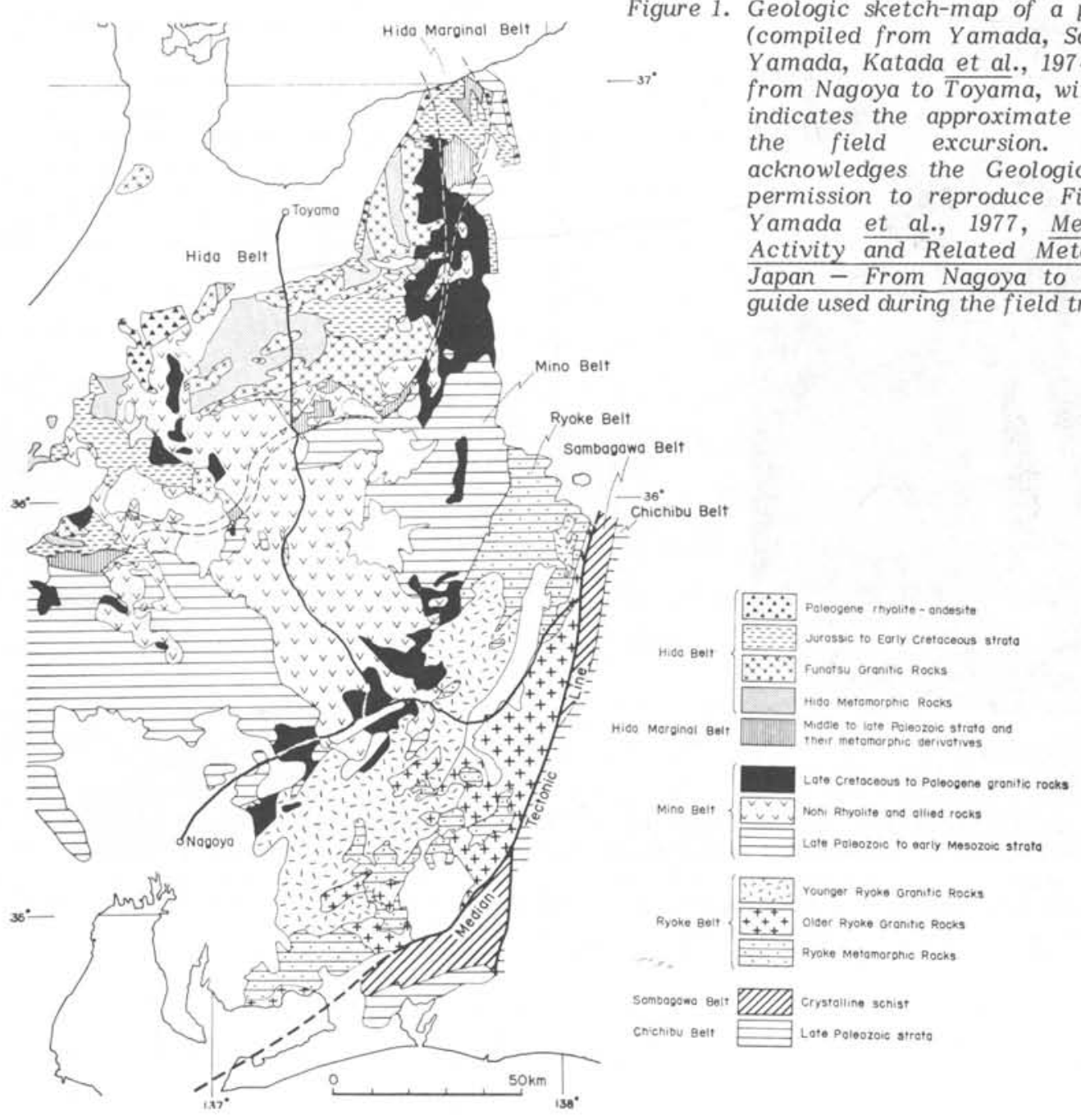

represented included Japan, Korea, USA, Australia, Thailand, Canada, Peru, Great Britain, Chile and USSR. A Unesco observer from Jakarta attended the symposium in Toyama.

\section{The Field Excursions}

The field trip in Japan followed a ruggedly scenic route from Nagoya northward across central Honshu to Toyama (see Fig. 1). It crossed the main geotectonic belts of the inner side of southwest Japan, north of the Median Tectonic Line. The field trip leaders - Yoshikazu Hayama and Tetsuo Yamada for the Ryoke belt, Naotoshi Yamada for the Mino belt, and Tamotsu Nozawa for the Hida belt produced a useful summary of the geology of central Honshu in their published guide (see Fig. 1).

Figure 1. Geologic sketch-map of a part of central Honshu compiled from Yamada, Sakamoto et al., 1974; with a branch to the east, indicates the approximate route followed during the field excursion. Episodes gratefully Geological Survey of Japan's Igneous Japan - From Nagoya to Toyama, the published guide used during the field trip. 
In the Ryoke belt, metasedimentary gneiss and schist have been intruded by granitoids. To the northwest, the metamorphic rocks pass into unmetamorphosed sedimentary (mainly pelitic and psammitic) strata of Paleozoic age, but to the southeast, the metamorphic grade increases through the biotite, cordierite, first sillimanite, and second sillimanite (fibrolite) isograds.

The granitic rocks are categorized in two age groups, one older and one younger than the Upper Cretaceous Nohi Rhyolite (see Fig. 1 and Table 1). The older Ryoke granitoids have been cataclastically deformed and are gneissose. Thought to have been emplaced in the Early Cretaceous, the older granitoids are mainly granodiorite and tonalite but include subordinate quartz diorite, granite, and gabbro. The younger granitoids are granodiorite and granite; undeformed, they are thought to have been emplaced in the Early Cretaceous.

Table 1

\section{Summary of geology in central Honshu (from Yamada et al., 1977)}

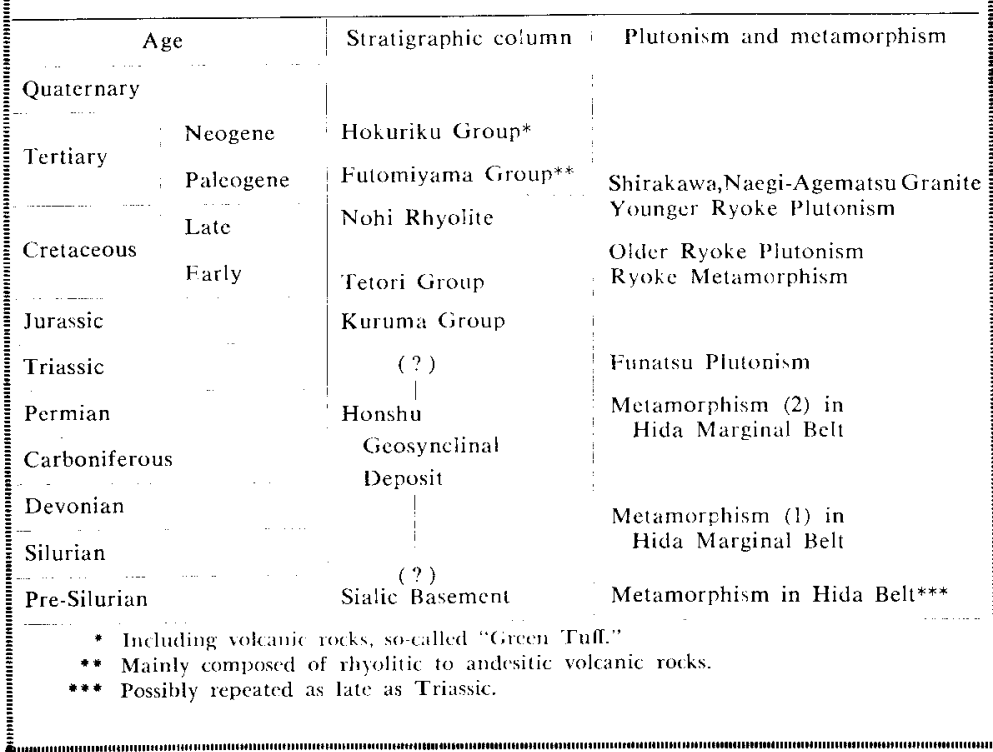

We examined several outcrops of gneissose granitoids the Ikuta Granite, the Tenryukyo Granite, and the Hiji Granite. Cataclastic foliations and lineations are conspicuous in all except the Ikuta Granite, and in some places, the rocks have been reduced to mylonites, especially close to the Median Tectonic Line. Within 500 meters of the Median Tectonic Line, all of the rocks are mylonitized. Porphyroidlike mylonite, in which the porphyroclasts are relict plagioclase crystals, grades into the Hiji Granite. However, large megacrysts of K-feldspar in mylonitized parts of the Tenryukyo Granite are interpreted to be porphyroblasts rather than phenocrysts.

The close spatial association of the deformed older granitoids with the Median Tectonic Line suggests that movements along the Median Tectonic Line may have coincided with deformations that produced the cataclastic features in the older granitoids.
Mino Belt

The Mino belt (part of the more extensive Tamba belt) is occupied mainly by unmetamorphosed geosynclinal strata of Paleozoic, mainly Permian, and probably Triassic age. Where the field trip route crossed this belt, the rocks were found to be unconformably overlain by the Upper Cretaceous Nohi Rhyolite, an extensive formation that underlies about $5,000 \mathrm{~km}^{2}$ and has an estimated volume of about $10,000 \mathrm{~km}^{3}$

(Fig. 1). The Nohi Rhyolite is intruded by the younger Ryoke granitoids and by the Naegi-Agematsu Granite in the south and the Shirakawa Granite in the north, which are believed to be genetically related to the Nohi Rhyolite in a volcanoplutonic complex.

Prior to 1961 , the Nohi Rhyolite was usually referred to as quartz porphyry, but detailed studies show that it is composed of many ash-flow tuff sheets ranging between 200 and 500 meters thick, and lesser amounts of clastic sediment and unwelded pyroclastic rocks. This unit is dominated by densely welded and devitrified rhyolite and rhyodacite. Phenocrysts of quartz, plagioclase, $\mathrm{K}$-feldspar and altered mafic minerals are ubiquitous, and lithic fragments are common in some outcrops.

Most of the granitoids appear to be biotite granites. Pegmatites and miarolitic cavities, some several centimeters across, indicate that the exposures were near the ground surface when the granitoids were emplaced. The rock appeared to be quite massive, and neither primary magmatic nor secondary cataclastic structures could be seen.

\section{Hida Belt}

In this belt, the Hida metamorphic rocks are intruded by the Funatsu granitoids. Both groups of rocks are unconformably overlain by the Tetori Group, which ranges in age from Middle Jurassic to Early Cretaceous. The Hida metamorphic rocks are schists and gneisses that are considered to have been derived from sandstone and minor amounts of intercalated limestone, mudstone, and volcanic rocks. Sillimanite is common and is accompanied in some places by andalusite and cordierite, but kyanite and staurolite occur in the northeastern part of the belt. Neither the age of the rocks nor their times of metamorphism are certain except that both are pre-Middle Jurassic. Isotopic ages range from Precambrian to Jurassic.

The Funatsu granitoids include different ranges of composition. Shimonomoto-type granitoids are quartz diorite and tonalite, whereas Funatsu-type granitoids are granodiorite and granite. The latter intrude the Shimonomoto-type granitoids. The age of the granitoids is not established, but they are believed to be Late Permian or Early Triassic.

Most of the outcrops we examined were granitoids of the Shimonomoto type; all were deformed and some mylonitized. The rock in the single outcrop of the Funatsutype granitoid appeared massive and undeformed. On the whole, we saw too few outcrops to draw any general conclusion as to the deformation of the two types.

\section{South Korea}

This field trip began at Pusan in the southeast corner of the Korean Peninsula and proceeded along a magnificent route a little west of north, diagonally across the Korean Peninsula, to Seoul. The route crossed the nor theast-trending structural grain of Korea, which is called the Sinian direction. Ok Joon Kim and Dai Sung Lee, along with several other Korean geologists, served as leaders and guides for parts of the trip. 
Precambrian rocks underlie most of South Korea. They are extensively intruded by Mesozoic granitoids; along the southeast side near Pusan and in the smaller areas in the southwest part they are overlain by the Cretaceous Yongsang system and associated Kyongsang volcanic rocks.

Most of the granitoids have been assigned to two groups, the Daebo granitoids of Jurassic and possibly early Cretaceous age, and the Bulgugsa granitoids of Cretaceous and possibly early Tertiary age. Both groups probably include granitoids of a wide range of ages, because $\mathrm{K} / \mathrm{Ar}$ and $\mathrm{Rb} / \mathrm{Sr}$ age dates from the Daebo granitoids span the whole Jurassic, while the ones from the Bulgugsa granitoids span the whole of the Cretaceous. The Daebo granitoids occur in extensive and widespread strips that trend northeast, following the grain in the Precambrian formations. By contrast, the Bulgugsa granitoids occur in relatively small subequant plutons that are limited to the southeast part of the Korean Peninsula, where they intrude both the Precambrian and the Cretaceous Kyongsang system.

The two groups are very different. The Daebo granitoids are mostly medium grained, foliated, rather dark, hornblende biotite granodiorite containing mafic inclusions. The rocks we saw are equigranular, except for one outcrop in which the rock is porphyritic. They resemble mesozonal I-type granitoids from the batholiths of North America. These granitoids are thought to have been emplaced during the Jurassic Daebo orogeny, considered to be the strongest orogeny to have affected Korea.

In contrast, the Bulgugsa granitoids are mostly medium to fine-grained, massive, biotite granite of somewhat variable texture. Commonly they contain miarolitic cavities and other evidence of having been emplaced at a high level. They are thought to have been emplaced during the very mild Bulgugsa disturbance, which produced open folds and broad warps in the Cretaceous strata of the southeast part of the Korean peninsula.

\section{The Symposium}

At least eight of the papers presented at the symposium were devoted specifically to the general theme: plutonism in relation to volcanism and metamorphism. Notably, Aramaki, Takahashi, and Nozawa described two volcano-plutonic complexes in the outer zone of southwest Japan in which the plutonic and volcanic rocks are comagmatic. Large-scale vesiculation of magma in the Kumano complex produced an extensive ash-flow sheet, which was later engulfed by rising magma that formed gigantic lava lakes. In the Okueyama complex, nested cauldrons were invaded underground by a large flat-topped pluton that reached to within $3 \mathrm{~km}$ of the surface. The exposed upper 1000 meters grades (from the top downward) from leucocratic granite to granodiorite.

Bateman and Nokleberg outlined the variations in the compositionally zoned Mount Givens Granodiorite of California and proposed a crystal fractionation model to explain the compositional patterns. Hildreth then described the systematic compositional variations in the pyroclastic desposits erupted from the nearby Long Valley Caldera, and concluded that crystal fractionation mechanisms cannot explain the compositional variations in comagmatic pyroclastic sequences.

Pitcher spoke on the centered complexes of Peru and related them to the older surrounding plutonic rocks and to the now-eroded volcanic edifices above. Roddick and Woodsworth interpreted plutonism in the Coast Plutonic complexes of British Columbia to be the result of regional metamorphism and not its cause. They also suggested that volcanism associated with plutonism may originate at the base rather than the top of a pluton. Silver reported that Rb$\mathrm{Sr}$ plots of the granitoids in Baja California, Mexico are characteristic for different field domains and that the

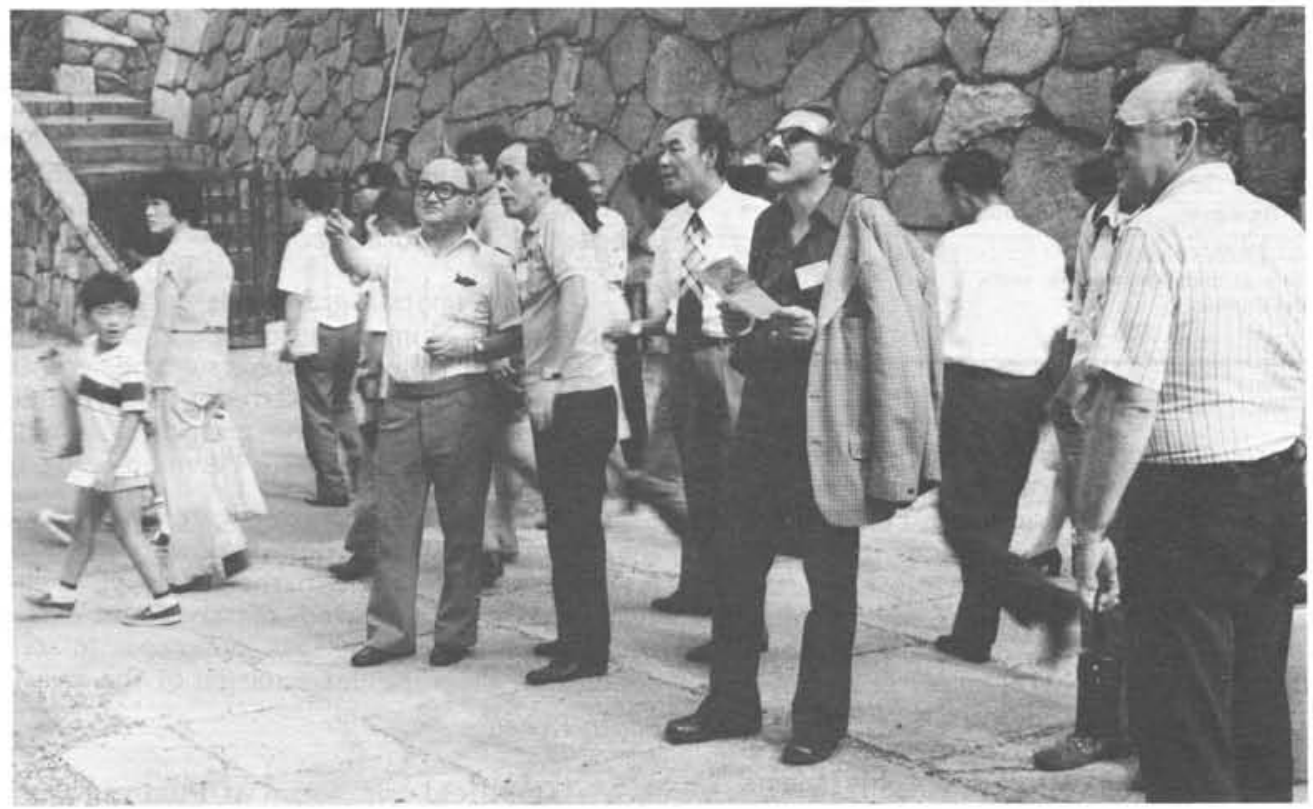

Dr. T. Nozawa (Japan) field trip leader shows how granite has been used in building the walls of Nagoya Castle. To the right of Dr. Nozawa, are Dr. Y. Hayama (Japan) a co-leader of the field trip, Professor Moon Sung Cha (South Korea), Professor L. Aguirre (Chile) and Professor L.T. Silver (USA). (Photograph: W.W. Hutchison, Geological Survey of Canada, No. 1-5-77.) 
differences between domains cannot be explained by contamination from the country rocks.

Plutonism in Japan received excellent coverage. Sohma interpreted the Hida metamorphic complex to be the result of interplay between tectonism, metamorphism, and plutonism. T. Kano observed that certain types of augen gneisses in the Hida metamorphic complex were derived from gneisses by cataclastic deformation followed by potassium metasomatism under greenschist facies conditions. H. Kano concluded from a survey of rock types that a large-scale volcano-plutonic complex existed in Japan during the Silurian and Devonian, which he felt indicated that an ensialic or continental rather than an oceanic environment existed at that time.

Nabetani and $\mathrm{H}$. Kano described the results of gravity and magnetic studies of the granitoids in the Kitakami Mountainland of northeastern Japan. The studies revealed several compositionally zoned plutons with felsic cores, which they interpreted as having been eroded to various depths. Sato described gneissic xenoliths from the Yakushima Granite of southwest Japan, which contain aluminum silicates, cordierite, and muscovite. Kizaki described the Hidaka metamorphic belt of Hokkaido and traced the generation of granite and migmatite in a diapiric model. Grapes presented a tectonic model for the development of the MesozoicCenozoic arc-trench, the Neogene orogeny, and the Hidaka metamorphic belt of Hokkaido. Ikeda compared the compositions of the granitic rocks of Japan with their wall rocks and found a good correlation, which he attributed to assimilation. Honma and Kagami reported on ${ }^{18} \mathrm{O} /{ }^{16} \mathrm{O}$ obtained from the granitic rocks of the Chugoku Province, and Kuroda, Suzuoki, and Matsuo reported on hydrogen isotope studies of Japanese granitic rocks.

Three papers dealt with ore deposits. One of the most significant and intriguing presentations was that of White, Beams and Cramer, who postulated that tin is preferentially related to S-type granites because of a high concentration of $\mathrm{Sn}, \mathrm{F}, \mathrm{B}$, and water in the sedimentary source rocks. Suensilpong related the tin belt of southeast Asia to episodic eastward subduction of the Indian Ocean plate beneath the Thai-Malaysia Peninsula. Akiyama and Konagai described the relation of the skarn-type lead and zinc deposits in the Kamioka mine to migmatites and to porphyries, which were examined during the field trip.

Bound volumes of the papers presented at meetings and the field guides were supplied to each participant. Since English was the native language of only a few participants, these volumes were extremely helpful in aiding communication.
Particularly impressive throughout the excursions and the symposium were the superb organizational skills of the Japanese and the Koreans. Their warm hospitality created an atmosphere conducive to open discussions and to the free flow of ideas. The success of the conference stands as a testimonial to the efforts of the organizing committees and their leaders - Kenzo Yagi and Tomotsu Nozawa in Japan and Ok Joon Kim, Dai Sung Lee and Sang Ho Um in Korea.

\section{References}

Yamada, N., Katada, M., Hayama, Y., Yamada, T., Nakai, Y., Kutsukake, T., Suwa, K. and Miyakawa, K., 1974, Geological map of the Ryoke Belt, central Japan, Scale 1:200,000: Geol. Surv. Japan, Misc. Map Ser. 18.

Yamada, N., Sakamoto, T., Nozawa, T. and Ende, T., 1974, The geological sheet-map "Kanazawa", Scale 1:500,000. 2nd Edition: Geol. Surv. Japan.

Yamada, N., Nozawa, T., Hayama, Y. and Yamada, T. 1977, Mesozoic Felsic Igneous Activity and Related Metamorphism in Central Japan - From Nagoya to Toyama: Geol. Surv. Japan, Guidebook for Excursion 4.

(Note: An annotated bibliography of 1600 references to Circum-Pacific Plutonism has been compiled-see "Bibliographies", p. 42)

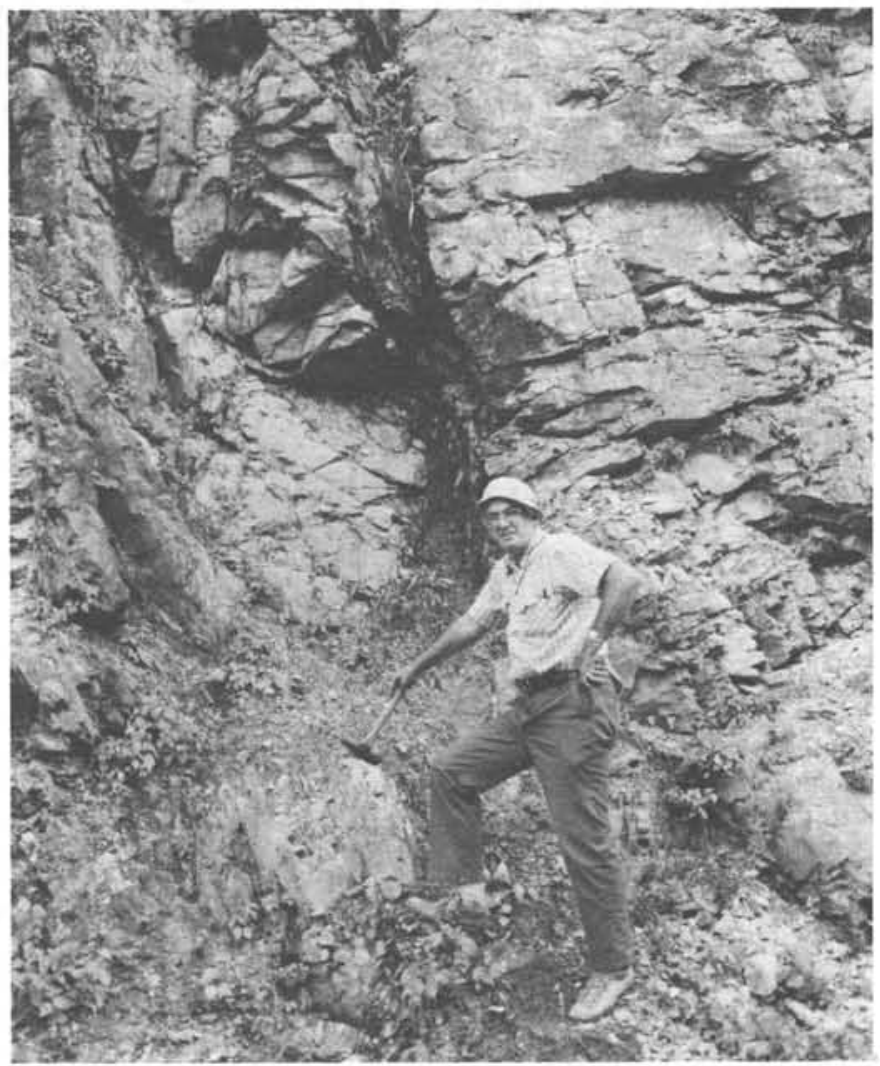

Dr. Bateman astride the Median Tectonic Line. To the left (east) are sheared schists of the Sambagawa Metamorphic (glaucophane-bearing) Belt. To the right (west) is a mylonitic facies of the Hiji Granite. (Photograph: W.W. Hutchison, Geological Survey of Canada, No. 1-10-77.)

ABOUT THE AUTHOR: A geologist with the United States Geological Survey since 1942, Dr. Paul Bateman has spent the greater part of his professional life studying the origin and evolution of granitic rocks in the Sierra Nevada and neighbouring districts of western U.S.A. Active in the IUGS scientific program, he was a member of the Subcommission on Systematics of Igneous Rocks, and was involved in drafting the initial plans for the IGCP (Budapest, 1969). Dr. Bateman has been head of the Circum-Pacific Plutonism Project since its inception in 1972. 